\title{
Exploring Materiality and Connectivity in Anthropology and Beyond
}

Edited by Philipp Schorch, Martin Saxer and Marlen Elders 
First published in 2020 by

UCL Press

University College London

Gower Street

London WC1E 6BT

Available to download free: www.uclpress.co.uk

Text (C) Contributors, 2020

Images (C) Contributors, 2020

The authors have asserted their rights under the Copyright, Designs and Patents Act 1988 to be identified as the authors of this work.

A CIP catalogue record for this book is available from The British Library.

This book is published under a Creative Commons 4.0 International license (CC BY 4.0). This license allows you to share, copy, distribute and transmit the work; to adapt the work and to make commercial use of the work providing attribution is made to the authors (but not in any way that suggests that they endorse you or your use of the work). Attribution should include the following information:

Schorch, P., Saxer, M. and Elders, M. (eds). 2020. Exploring Materiality and Connectivity in Anthropology and Beyond. London: UCL Press. DOI: https://doi. org/10.14324/111.9781787357488

Further details about Creative Commons licenses are available at http://creativecommons.org/licenses/

Any third-party material in this book is published under the book's Creative Commons license unless indicated otherwise in the credit line to the material. If you would like to reuse any third-party material not covered by the book's Creative Commons license, you will need to obtain permission directly from the copyright holder.

ISBN: 978-1-78735-750-1 (Hbk.)

ISBN: 978-1-78735-749-5 (Pbk.)

ISBN: 978-1-78735-748-8 (PDF)

ISBN: 978-1-78735-751-8 (epub)

ISBN: 978-1-78735-752-5 (mobi)

DOI: https://doi.org/10.14324/111.9781787357488 


\section{Contents}

List of figures vii

Notes on contributors xii

Acknowledgements xvii

Introduction: Materiality and Connectivity $\quad 1$

Martin Saxer and Philipp Schorch

Part I: Conceptual Grounds $\quad 15$

1. In the gathering shadows of material things 17 Tim Ingold

2. Doing/changing things/us 36 Philipp W. Stockhammer

Part II: Movement and Growth

3. Becoming imperial: the politicisation of the gift in Atlantic Africa

Julia T. S. Binter

4. How pilgrimage souvenirs turn into religious remittances and powerful medicine

Catrien Notermans and Jean Kommers

Intervention

5. Invoking the gods, or the apotheosis of the Barbie doll Natalie Göltenboth

6. Stallions of the Indian Ocean

Srinivas Reddy 
7. Labelling, packaging, scanning: paths and diversions of mobile phones in the Andes

Juliane Müller

Intervention

8. Establishing intimacy through mobile phone connections Anna-Maria Walter

Part III: Dissolution and Traces

9. Smoky relations: beyond dichotomies of substance on the Tibetan Plateau

Gillian G. Tan

Intervention

10. What remains: the things that fall to the side of everyday life Marc Higgin

11. Apocalyptic sublimes and the recalibration of distance: doing art-anthropology in post-disaster Japan Jennifer Clarke

12. Towards a fragmented ethnography? Walking along debris in Armero, Colombia

Lorenzo Granada

Intervention

13. Remembering and non-remembering among the Yanomami Gabriele Herzog-Schröder

14. The matter of erasure: making room for utopia at Nonoalco-Tlatelolco, Mexico City Adam Kaasa

15. Refugee life jackets thrown off but not away: connecting materialities in upcycling initiatives Elia Petridou Intervention

16. Tamga tash: a tale of stones, stories and travelling immobiles 249 Lisa Francesca Rail 


\title{
8 Intervention
}

\section{Establishing intimacy through mobile phone connections}

\author{
Anna-Maria Walter
}

This chapter seeks to tease out the relationship between the material perception of human life and virtual connections made through mobile phones. In both spheres, knowledge is fabricated through experience, in the first, through the body, in the second, it would seem, rather through the mind. Showing how love relationships materialise through mobile phones, I argue for a means of overcoming this epistemological dichotomy and show how users embody virtual experiences. Through the presentation of fieldwork findings, I tackle the question of how we can conceptualise virtual connections and how they redefine interpersonal relationships, thereby affecting established norms and values. While many social scientists have emphasised the affective dimensions of human bodies (cf. Csordas 1990; Desjarlais and Throop 2011; Grosz 1994; Ingold 2000), the virtual is generally associated with mere mental imaginations. The philosopher Brian Massumi, famous for his work on experience and affect, describes the virtual as devoid of sensible qualities but, more importantly, identifies it as 'fleeting' (Massumi 2002, 133), thus offering endless potential: 'new thoughts may be thought, new feelings felt' (Massumi 2002, 141). This chapter recognises the potentialities of young couples' virtual phone chats. The emotional and embodied effects ${ }^{1}$ of mobile phone connections are exemplary of a thing tie (Saxer and Schorch, Introduction to this volume) that transcends the concrete thing. What counts is not the material quality

Figure 8.1 Curtain of veils shielding off private space from public workshop area. Installation by Anna-Maria Walter, Symposium Connecting Materialities/Material Connectivities, Munich 2017, LMU Center for Advanced Studies. Photo by the author.

Figure 8.2 Peeking through the flexible wall of veils into a separate private sphere. Installation by Anna-Maria Walter, Symposium Connecting Materialities/Material Connectivities, Munich 2017, LMU Center for Advanced Studies. Photo by the author. 
of the handset; ${ }^{2}$ rather, the mobile phone derives its meaning from the connections it facilitates.

Through a curtain of veils and the snapshot of a wedding ceremony, my intervention seeks to show the ways in which gender segregation determines social life in the high mountain areas of Gilgit in northern Pakistan and continues in conjugal relationships. The obstructive wall made of Pakistani headscarves (see Figure 8.1) materialises the cultural practice of parda (literally meaning curtain), which stands for gendered life-worlds and veiling.

Although the colourful barrier gives a cheerful impression, many people walking past it do not notice what is hidden behind; its material presence invokes restraint and serves its function of seclusion well. Only those who dare to peek carefully through or push aside one of the veils discover the comfort and cosiness of a private room. Often it was just a slight movement of the light fabric by the wind or a passer-by that piqued people's curiosity and drew their attention to the permeability of the wall (see Figure 8.2).

In addition to providing a welcome refuge from the busy workshop environment, the privacy of the room also propels visitors to a semi-private family setting in the Gilgit area. The moving images of a wedding ceremony (see Figure 8.3) show a self-conscious couple sitting in the midst of their extended kin, feeding each other different foods to express mutual care. In accordance with local norms and expectations that the other gender is generally avoided, the bride feels particularly embarrassed at the display of conjugal affection in front of others.

When alone, however, the couple are much more at ease with each other. They had been in touch via mobile phones for about a year before this wedding ceremony. After the arrangement of their marriage by their families, the individuals themselves fell in love, exchanging messages, holding long phone conversations and organising the fiancé's occasional visits to the girl's family. Before the introduction of mobile phones, even spouses whose marriage had already been arranged were expected to avoid each other until they were fully married. Lacking the possibility to meet in private, they could not establish an intimate relationship, either emotional nor physical. Figure 8.4, however, shows a fairly explicit excerpt from a sexually charged SMS chat between newlyweds, who study at universities in different cities. Despite older stereotypes of spousal avoidance, their intimate thoughts, affection and desires are manifest in these messages.

The erotic conversation also challenges local scepticism towards female emotional expressions. In the Gilgit area, women cover themselves for various reasons, such as religious observance and fashion, but most importantly to conform with a highly embodied form of modesty (Walter 
2016). Parda, as a performative social practice as well as as an expression of morals and values, serves to regulate interactions between women and men, especially strangers, imposing on them distance and reserve. Leaving behind the public arena, only men who are family members enter the women's domain of the private household. Among close relatives gender segregation is relaxed, but elements of distance and reserve continue to characterise female-male interaction. Because conjugal intimacy is directly associated with sexuality, even married couples avoid displaying their mutual affection in front of others. For women it is therefore extremely important to assess where one literally stands to know how to behave in a certain place, whether in private or public. To engaged couples or newly-weds, the new medium of mobile phones guarantees privacy from surveillance and enables progressive familiarisation to build up conjugal intimacy even before they move together into their future family home.

Many of my interlocutors emphasised that mobile phone connections take place in an obscure, in-between site, one that is uncoupled from the material characteristic of sensory perception. As one young woman explained to me, 'It feels like a third space ... a mobile world. In this space, only voices meet and faces appear in the mind.' Facilitating invisible links between places that are conventionally distinct potentially disrupts spatial segregation and transgresses the binary of inside-outside. In telecommunication networks, voice and mind can travel over geographical and social boundaries but are still rooted in on-site experiences. An 18-year-old female college student from Gilgit describes the virtual encounter:

When I write messages and, for example, have to laugh, the other's face comes to my mind. If the other person says that I'm here or there, in a shop, or eating apricots, or whatsoever, I can picture them without seeing; ... that she would be laughing like that, they might be sitting in the shop like that and so on.

The young woman imagines the people she is talking to on the basis of shared experiences. Even if she has never seen the location where the other one is, she can still draw from a cultural repository to fill in missing details, such as imagining the busy life in a hardware shop. She does not have to encounter her interlocutor in person to 'meet' her or him on the phone. Although these meetings in mobile space include little immediate sensory stimulation, they still affect users on an emotional level, influence their physical presence and leave a mark on existing relationships (Livholts and Bryant 2013, 163). In fact, the content of these messages has an impact on the emotional state of all involved. An SMS in a joking style might cheer up a friend and transmit 


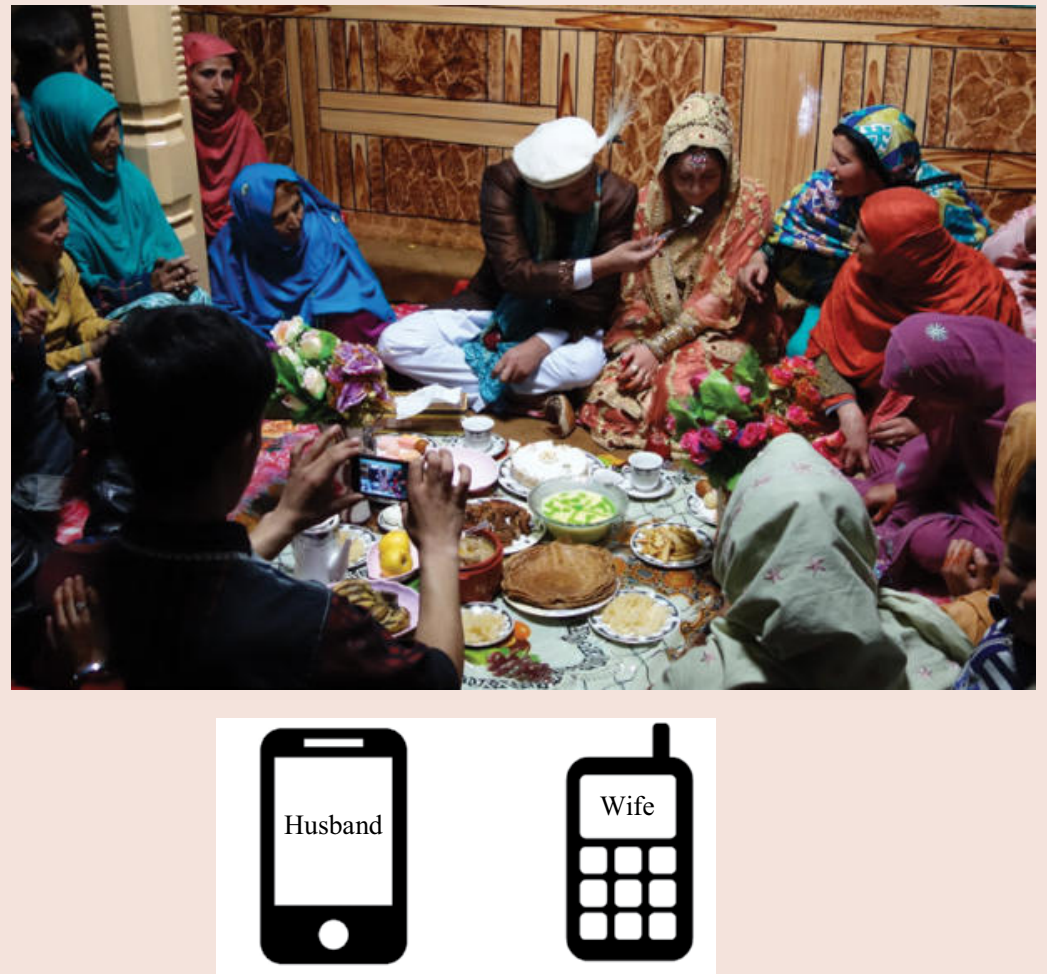

I miss you, darling, it would be so much fun if I was there,

I would also do some naughty things.

Too bad, darling. If I was there. What naughty thing would you do, darling? Anything in mind?

Hahaha, you're right. I would hold you from the back, put my hand down and kiss.

You slut. I swear by you that I dreamt last night that you were in front ... hahaha

Do you swear? What happened?

The way I was at my sister's once. Hahaha. Yes. You know what, I was in great pleasure.

Do you swear? Did you enjoy it?

Yes, darling, very much.

Ummmmahhhhh [Onomatopoeic kiss]. 
a sense of connection and intimacy, as well as making the sender happy as she can picture the recipient laughing at the message sent.

What the sociologist Christian Licoppe introduces as 'connected presence' (Licoppe 2004, 135) does not necessarily describe the bridging of distance, the virtual travel of one interlocutor to the other (Archambault 2012), but rather captures the meaningfully shared experience that takes place in the virtual space of mobile phone connections. On the other hand, it might be the lack of non-verbal clues through one's tone of voice together with the lack of gestural clues from face-to-face encounters - that is responsible for heightened expressions of feelings in SMSes. Although a female lover would never say such things out loud, she frequently types 'Ummahhh' (for kiss) or 'januuuuu' (darling). This way, mobile phone connections allow the testing of boundaries and penetrate social norms and values. Both examples - the above quote from the young woman from Gilgit as well as blunt sexting - exemplify users' capability of inhabiting an abstract space of fleeting, folding and vanishing images (cf. Massumi 2002,133 ) which challenges older presumptions that the virtual lacks sensible qualities. Mobile space is experienced and defined through affective dimensions of the body, such as hearing the other's voice, imagining her face or being emotionally moved by the words in a message. At the same time, the lack of somatic qualities defines interactions in space, which are, however, not completely detached from social values in place.

To grasp the immediacy of the mobile world, we need a reconceptualisation of the virtual and the material. I agree with the anthropologists Heather Horst and Daniel Miller that 'the virtual is more a new kind of place rather than a form of placelessness' (Horst and Miller 2012, 27), and suggest that social scientists draw attention to material characteristics that permeate the virtual. As Licoppe observed, communication in such virtual spaces radically revolutionises our understanding of social interaction that takes place face to face. Mobile phones allow users to build and tend to their links without ever meeting, thereby seemingly rendering shared somatic experiences insignificant (Licoppe 2004, 139). Nevertheless, virtual social relationships can never be completely uncoupled from material social life. Gilgiti women approximate behaviour suitable for female-male exchanges on mobile phones on the basis of their embodied sense of modesty. For example, they do not answer calls from unknown numbers, just

Figure 8.3 Still from a film depicting a wedding ritual in Gilgit, northern Pakistan. Installation by Anna-Maria Walter, Symposium Connecting Materialities/Material Connectivities, Munich 2017, LMU Center for Advanced Studies. Photo by the author.

Figure 8.4 Chat in SMS messages by young married couple (like all quotes in this contribution, collected and translated from Urdu and Shina by Anna-Maria Walter). 
as they would not engage in small talk with a stranger in public. Invisible connections thus mostly align themselves with already existing paths and are less mobile than their potential implies. ${ }^{3}$ What is mobile, however, is the way experiences made in the ambiguous virtual space feed back into users' daily lives. Social relationships become modified between phone users; they tease out new practices, embody them and reinterpret cultural concepts. While staying in the socially acceptable framework of (future) conjugal relationships, young couples establish intimacy and feel love for each other. While this process takes place in mobile space, it has consequences for the gender and power dynamics that are in place and influences concrete practices, such as newly-weds' interactions with in-laws and their sexual lives.

Relationships made in virtual space can be as 'real' as on-site experiences. Virtual links thus challenge common perceptions of social life as direct encounter and, at the same time, revolutionise our understanding of the material. The physical and the virtual are intrinsically entangled. Just as an enclosed room affects people's perception of it in - or outside of its walls, the SMS chat between lovers takes on tangible form for them. Since young people in the Gilgit area primarily exchange messages on their mobile phones, they must develop creative ways to bridge the discrepancy between virtual and material presence. Through the thumb, they transfer emotions and stimulate the other's feelings. Longing for each other and experiencing sexual desire, as in the above SMS chat, are certainly somatic aspects of an intimacy that was, to a large extent, manifested through conversations in mobile space. As an integral part of love relationships in the Gilgit area, although mostly virtual, mobile phone connections leave material traces and feed back into life beyond mobile telephony. And, conversely, mobile space is appropriated on the basis of established norms and values. Intimate phone connections serve as prime examples of thing ties: both spheres manifest and evolve through the other, thus dissolving the prevailing dichotomy of virtual and material worlds.

Manoeuvring within the safe social space of an acknowledged relationship, Gilgiti girls (re)negotiate ideas of romantic love and erotic intimacy, aligning them with existing gender norms and their own sentiments of modesty. While the intervention described here enacts gender segregation through curtains, parda may shield women from the gaze of strangers. But veils and curtains are not impenetrable: their diaphanous and mobile character allows a glimpse of life behind them and asks to be permeated. Mobile phones connect these private places and offer a virtual platform on which to interact. What is not possible for young couples in on-site meetings is experienced, felt and embodied in mobile space. They develop 
emotional ties, affirm and reinforce loving bonds through SMS chats and phone calls, and effortlessly interlace the virtual and material worlds.

\section{Notes}

1. I identify emotions as motivational forces for people's actions; they reflect our innermost feelings as well as serving as transmitters of interaction between people and their environments (cf. Ahmed 2014). Current debates in the social sciences strive to circumvent analytically affects, emotions or feelings, and even sentiments. Affects are generally depicted as preconscious bodily sensations of unqualified intensity, whereas emotions involve a cognitive process of recognition and assessment of feelings, which themselves connote physiological and psychological conditions that result from a certain stimulus (Abu-Lughod 1986, 34; Barrett 2005, 263; Seigworth and Gregg 2010, 1; Massumi 2002, 27-9; Terada 2001, 4). Understanding embodiment as self-enforcing, sensory incorporation as well as enactment and renegotiation of norms and values, I do not support clear-cut distinctions between concepts of emotion: their boundaries are fluid; they conflate and co-construct each other; and they are all shaped by cultural models of interpretation and expression (Beatty 2014, 550; Röttger-Rössler and Stodulka 2014, 20).

2. While the actual practice of mobile phone use in daily life might seem to offer interesting insights, this focus on the handsets' material qualities is not supported by my fieldwork findings from Gilgit. Mobile phones are mostly experienced through the diffuse, abstract space they provide, rather than through paying attention to, for example, interruptions of conversations by vibrating phones.

3. Although mobile phone networks are often celebrated for uncoupling interpersonal communication from physical movement and facilitating new connections (Horst and Miller 2006; Pertierra 2005), most actual links between young couples in the Gilgit area follow previously established communication lines. Drawing on their earlier onsite experiences, users move along established pathways when negotiating their way within the new mobile infrastructures; thus phone connections mirror already existing knots (Ingold 2009, 32-4) which interweave people whose acquaintance is socially acceptable, in this example young couples whose (future) marital relationship has already been arranged and endorsed by their families.

\section{References}

Abu-Lughod, Lila. 1986. Veiled Sentiments: Honor and Poetry in a Bedouin Society. Berkeley and Los Angeles, and London: University of California Press.

Ahmed, Sara. 2014. The Cultural Politics of Emotion, 2nd edn. Edinburgh: Edinburgh University Press.

Archambault, Julie S. 2012. "“Travelling while sitting down": mobile phones, mobility and the communication landscape in Inhambane, Mozambique.' Africa 82 (3): 393-412.

Barrett, Lisa Feldman. 2005. 'Feeling is perceiving: core affect and conceptualization in the experience of emotion.' In Emotion and Consciousness, edited by Lisa Feldman Barrett, Paula M. Niedenthal and Piotr Winkielman, 255-84. New York and London: Guilford Press.

Beatty, Andrew. 2014. 'Anthropology and emotion.' Journal of the Royal Anthropological Institute 20 (3): 545-63.

Csordas, Thomas J. 1990. 'Embodiment as a paradigm for anthropology.' Ethos 18 (1): 5-47.

Desjarlais, Robert and Jason Throop. 2011. 'Phenomenological approaches in anthropology.' Annual Review of Anthropology 40 (1): 87-102.

Grosz, Elisabeth. 1994. Volatile Bodies: Toward a Corporeal Feminism. Bloomington, IN: Indiana University Press. 
Horst, Heather and Daniel Miller. 2006. The Cell Phone: An Anthropology of Communication. Oxford and New York: Berg.

Horst, Heather and Daniel Miller. 2012. Digital Anthropology. London and New York: Berg.

Ingold, Tim. 2000. The Perception of the Environment: Essays on Livelihood, Dwelling and Skill. London and New York: Routledge.

Ingold, Tim. 2009. 'Against space: place, movement, knowledge.' In Boundless Worlds: An Anthropological Approach to Movement, edited by Peter Wynn Kirby, 29-43. New York and Oxford: Berghahn Books.

Licoppe, Christian. 2004. "'Connected" presence: the emergence of a new repertoire for managing social relationships in a changing communication technoscape.' Environment and Planning D: Society and Space 22 (1): 135-56.

Livholts, Mona and Lisa Bryant. 2013. 'Gender and the telephone: voice and emotions shaping and gendering space.' Human Technology 9 (2): 157-70.

Massumi, Brian. 2002. Parables for the Virtual: Movement, Affect, Sensation. Durham, NC: Duke University Press.

Miller, Daniel and Heather Horst. 2012. 'The digital and the human: a prospectus for digital anthropology.' In Digital Anthropology, edited by Heather Horst and Daniel Miller, 3-35. London and New York: Berg.

Pertierra, Raul. 2005. 'Mobile phones, identity and discursive intimacy.' Human Technology 1 (1): 23-44.

Röttger-Rössler, Birgitt and Thomas Stodulka. 2014. 'Introduction: the emotional make-up of marginality and stigma.' In Feelings at the Margins: Dealing with Violence, Stigma and Isolation in Indonesia, edited by Thomas Stodulka and Birgitt Röttger-Rössler, 11-29. Frankfurt am Main and New York: Campus.

Seigworth, Gregory J. and Melissa Gregg. 2010. 'An inventory of shimmers.' In The Affect Theory Reader, edited by Melissa Gregg and Gregory J. Seigworth, 1-25. Durham, NC, and London: Duke University Press.

Terada, Rei. 2001. Feeling in Theory: Emotion after the 'Death of the Subject'. Cambridge, MA: Harvard University Press.

Walter, Anna-Maria. 2016. 'Between "pardah" and sexuality: double embodiment of "sharm" in Gilgit-Baltistan.' Rural Society 25 (2): 170-83. 